\title{
PENGARUH GOOD CORPORATE GOVERNANCE TERHADAP PROFITABILITAS DENGAN PENGUNGKAPAN TANGGUNG JAWAB SOSIAL PERUSAHAAN SEBAGAI VARIABEL MEDIATING PADA PERUSAHAAN MANUFAKTUR
}

\author{
RIE RIENITA PAALLO ${ }^{a}$ \\ ARDIANTO ${ }^{b}$ \\ ${ }^{\mathrm{a}}$ Sekolah Pascasarjana Universitas Airlangga ${ }^{\mathrm{b}}$ Fakultas Ekonomi dan Bisnis Universitas Airlangga \\ Email: rpaallo@yahoo.com ${ }^{\text {a }}$; ardianto@feb.unair.ac.id ${ }^{\text {b }}$
}

ARTICLE HISTORY

Received:

19 Februari 2020

Revised

16 March 2020

Accepted:

1 April 2020

Online available:

9 Mei 2020

Keywords:

Good Corporate

Governance,

Ownership,

Board of Directors,

Audit Committee,

CSR Disclosure,

Profitabillitas.

Kata Kunci:

Good Corporate

Governance,

Kepemilikan,

Dewan Komisaris,

Komite Audit,

Pengungkapan CSR,

Profitabillitas.

\section{ABSTRACT}

Introduction: This study examines the effect of good corporate governance on the profitability, either directly or through CSR as an mediating variable in manufacturing companies listed in Indonesia Stock Exchange in the period of 2008-2012.

Methods: Sampling method used is purposive sampling by using a balanced panel of data to obtain a sample of 135 companies._Good corporate governance as independent variables were measured using four internal mechanism that institutional ownership, managerial ownership, board of directors, and audit committees.he research hypotheses were tested using path analysis model.

Results: This study found that only institutional ownership had direct and significant impact on profitability. CSR disclosure only proven to be an mediating variable in the relationship between managerial ownership on the profitability of the company.

Conclusion and suggestion: Companies should pay attention in the form of social responsibility to the environment and society. 


\begin{abstract}
ABSTRAK
Penelitian ini bertujuan untuk mengetahui pengaruh good corporate governance terhadap profitabilitas perusahaan, baik secara langsung maupun melalui pengungkapan CSR sebagai variabel mediating pada perusahaan manufaktur yang terdaftar di Bursa Efek Indonesia periode 2008-2012. Metode penentuan sampel yang digunakan adalah purposive sampling dengan menggunakan data balanced panel sehingga didapatkan sampel sebanyak 135 perusahaan. Variabel bebas dalam penelitian ini adalah good corporate governance yang diukur dengan menggunakan empat struktur GCG yaitu kepemilikan institusional, kepemilikan manajerial, dewan komisaris, dan komite audit. Hipotesis dalam penelitian ini diuji dengan menggunakan model analsis jalur. Penelitian ini menemukan bahwa hanya kepemilikan institusional yang berpengaruh langsung dan signifikan terhadap profitabilitas. Pengungkapan CSR hanya terbukti dapat menjadi variabel mediating pada hubungan antara kepemilikan manajerial terhadap profitabilitas perusahaan.
\end{abstract}

\title{
INTRODUCTION
}

Kinerja keuangan yang baik dapat dilihat melalui tingkat profitabilitas perusahaan. Investor dapat melihat kemampuan suatu perusahaan dalam menghasilkan laba dengan melihat tingkat profitabilitas perusahaan. Profitabilitas yang baik dan cenderung mengalami peningkatan akan membuat investor untuk berani melakukan investasinya, sebaliknya jika profitabilitas rendah akan membuat investor menarik dananya dalam perusahaan. Informasi profitabilitas yang menjadi salah satu ukuran yang digunakan untuk menilai kinerja keuangan perusahaan juga dapat memberikan manfaat internal manajemen perusahaan. Pentingnya profitabilitas bagi perusahaan menuntut manajemen untuk melakukan usaha yang maksimal agar dapat menjaga dan terus meningkatkan profitabilitas perusahaan.

Beberapa peristiwa yang terjadi dalam dunia bisnis internasional seperti krisis ekonomi yang terjadi pada tahun 1997 yang juga melanda beberapa negara di Asia termasuk Indonesia yang menyebabkan banyak perusahaan tidak mampu mempertahankan bisnisnya. Menurut Mallin (2004) terdapat beberapa kasus yang menjadi bukti bahwa diperlukan suatu sistem tata kelola yang baik, salah satunya adalah kasus kehancuran Enron Corp yang berpengaruh pada pasar keuangan global. Fenomena-fenomena terjadi baik diluar maupun didalam negeri tersebut menjadi latar belakang yang mendukung penerapan konsep good corporate governance.

Published by University of Airlangga.

This is an open access article under the CC BY license (https://creativecommons.org/licenses/by-sa/4.0/) 
Good corporate governance (GCG) berawal dari kesadaran masing-masing manajemen perusahaan dan pemerintah untuk menjalankan bisnis yang lebih baik dan tidak merugikan pihak-pihak yang terkait. Munculnya konsep good corporate governance ini menjadi salah satu aturan formal untuk memperbaiki kondisi perekonomian dengan berfokus pada bagaimana suatu organisasi dapat mengelola perusahaannya dengan baik yang nantinya akan memberikan manfaat bagi perusahaan itu sendiri. Good corporate governance merupakan konsep yang bertujuan untuk mengatur bagaimana organisasi dioperasikan dan dikontrol dengan baik melalui asas-asas dalam mekanisme penerapannya yaitu transparansi (transparancy), kemandirian (independency), akuntabilitas (accountability), pertanggungjawaban (responsibility), dan kewajaran (fairness).

Penerapan tata kelola yang baik dan benar dengan mempertimbangkan kerangka sustainability development akan mendukung perusahaan untuk dapat terus mengembangkan bisnisnya. Kerangka sustainability yang mencakup aspek ekonomi, lingkungan, dan sosial budaya untuk menjaga kelangsungan hidup organisasinya. Konsep sustainability development menekankan bahwa perusahaan tidak dapat hanya melihat aspek ekonomi atau keuangan saja, melainkan harus mempertimbangkan bagaimana perusahaan melakukan tanggung jawab sosialnya yang berhubungan dengan masyarakat. Kesadaran masyarakat ketika dunia bisnis semakin berkembang dan semakin banyak menggunakan sumber daya membuat masyarakat mulai mendesak agar perusahaan melakukan tindakan sosial yang bermanfaat bagi masyarakat dan lingkungan. Tindakan tersebut muncul sebagai konsep corporate social responsibility yang dilakukan untuk memperbaiki kesenjangan sosial dan kerusakan lingkungan yang terjadi akibat aktivitas operasional yang dijalankan perusahaan.

Di wilayah Asia, konsep corporate sosial responsibility mulai berkembang sejak tahun 1998, namun di Indonesia perkembanganya baru dimulai sejak tahun 2001. Pemerintah Indonesia juga ikut mendukung penerapan corporate sosial responsibility dengan mengeluarkan peraturan untuk pelaksanaan tanggung jawab sosial dan lingkungan melalui Undang-undang No. 40 tahun 2007 tentang perseroan terbatas dalam pasal 74 (UUPT No. 40 Tahun 2007) yang menetapkan bahwa perseroan memiliki kewajiban untuk melaksanakan tanggung jawab sosial dan lingkungan. Penerapan dan pengungkapan corporate sosial responsibility dapat menjadi salah satu keunggulan kompetitif perusahaan yaitu dengan meningkatkan ketertarikan investor terhadap perusahaan. Menurut Cheng dan Christiawan (2011), investor cenderung akan menanamkan modalnya pada perusahaan yang melakukan kegiatan corporate sosial responsibility yang berarti perusahaan tersebut mengedepankan aspek sustainability. Hal ini pada akhirnya tentu akan bermanfaat bagi perusahaan yaitu ketertarikan investor 
untuk menanamkan modalnya untuk pengembangan bisnis perusahaan yang mendukung pencapaian tingkat profitabilitas yang baik.

Industri manufaktur merupakan industri yang paling dekat dengan ketiga aspek dari konsep sustainability. Perusahaan manufaktur sangat berhubungan dengan lingkungan yaitu untuk bahan produksi dan pembuangan limbah dari sisa produksi. Selain target dari bisnis mereka adalah masyarakat sekitar maupun masyarakat secara luas, output dari bisnis mereka juga merupakan produk yang rata-rata digunakan seharihari oleh konsumen mereka. Diperlukan sistem tata kelola yang baik untuk dapat mengelolah kegiatan operasional yang tinggi pada perusahaan manufaktur. Hal ini menjadikan industri manufaktur sangat berpengaruh dalam perkembangan industri dalam suatu Negara.

Di Indonesia, perkembangan industri manufaktur secara umum dapat dilihat pada perusahaan publik manufaktur yang terdaftar di Bursa Efek Indonesia. Jumlah industri manufaktur di Indonesia lebih banyak dibanding industri lain yang terdaftar di Bursa Efek Indonesia. Hal ini juga menggambarkan bahwa kondisi persaingan sudah semakin meningkat, baik secara nasional maupun dalam persaingan global. Menurut Alijoyo dan Subarto (2004), hal ini menjadi alasan Pemerintah Indonesia mengeluarkan berbagai inisiatif strategik seperti restrukturisasi dari reformasi good corporate governance untuk mendukung perkembangan bisnis perusahaan-perusahaan di Indonesia.

Beberapa penelitian terdahulu yang melihat hubungan antara penerapan good corporate governance, pengungkapan corporate sosial responsibility dan profitabilitas digunakan dalam penelitian ini sebagai slah satu bahan pertimbangan. Penelitian Setyarini dan Melvie (2011), Jamali et. al. (2008) mengindikasikan bahwa mekanisme internal good corporate governance berpengaruh pada pengungkapan tanggung jawab sosial. Penelitian untuk melihat hubungan pengaruh diantara kedua variabel tersebut dilakukan oleh Jo dan Harjoto (2012) yang menemukan bahwa CSR tidak mempengaruhi variable CG, dan menegaskan penelitian-penelitian sebelumnya bahwa variable CG positif mempengaruhi CSR perusahaan. Pengungkapan corporate sosial responsibility perusahaan akan memberikan pengaruh pada profitabilitas perusahaan. Penelitian yang mendukung hal ini dilakukan oleh Ekatah et. al. (2011), Jo dan Harjoto (2012). Profitabilitas perusahaan sebagai salah satu tujuan utama perusahaan dapat tercapai jika perusahaan mampu melakukan kegiatan bisnisnya dengan efisien dan efektif melalui tata kelola yang baik atau good corporate governance. Penelitian yang membuktikan pengaruh good corporate governance terhadap profitabilitas dilakukan oleh Wilopo (2011) juga Setyawan dan Putri (2013). Namun menurut Riandi dan Siregar (2011), Coskun dan Sayilir (2012), juga Aggarwal (2013) mengungkapkan bahwa tidak ada 
hubungan yang signifikan antara good corporate governance dengan kinerja keuangan atau ROA sebagai proksi dalam pengukurannya.

\section{LITERATURE REVIEW}

Keberadaan investor institusional, misalnya lembaga keuangan, memiliki karakter sebagai sophisticated investor yang akan menjalankan tugas monitoring mereka dengan lebih bersifat profesional. Semakin tinggi tingkat monitoring tentu akan menuntut manajemen untuk melakukan tugas dan tanggung jawabnya dengan sebaik mungkin termasuk pelaksanaan kegiatan tanggung jawab sosial dan menyediakan informasi yang relevan dalam bentuk pengungkapan tanggung jawab sosial. Sesuai dengan teori legitimasi, dimana investor institusional akan memonitoring dan mempengaruhi manajemen dalam melakukan hubungan timbal balik antara perusahaan dengan lingkungan dan masyarakat sekitar agar perusahaan mendapatkan dukungan dalam menjalankan dan mempertahankan bisnis mereka sehingga dapat meningkatkan kinerja perusahaan. Sesuai dengan teori stakeholder, dimana tanggung jawab perusahaan tidak hanya pada para pemilik saham (shareholder), melainkan perusahaan juga bertanggung jawab untuk memberikan manfaat bagi para stakeholder. Hal ini bertujuan agar para stakeholder tersebut dapat terus memberikan dukungan bagi perusahaan dalam menjalankan bisnisnya. Sesuai dengan teori social contract, dimana bertujuan untuk mencapai keselarasan, keserasian, dan keseimbangan dalam hubungan interelasi yang terjadi pada kehidupan sosial masyarakat sehingga dapat memberikan dampak positif bagi kinerja perusahaan dan mencapai tujuan para investor institusional. Hipotesis ini didukung oleh beberapa hasil penelitian terdahulu. Hasil penelitian Setyarini dan Paramitha (2011) yang menunjukkan bahwa kepemilikan institusional berpengaruh terhadap pengungkapan CSR. Hasil penelitian Jo dan Harjoto (2011) juga menunjukkan bahwa CSR berpengaruh terhadap mekanisme internal GCG, termasuk kepemilikan insitusional.

Manfaat pengungkapan CSR yang dilakukan perusahaan sesuai dengan yang disampaikan oleh Kotler dan Lee (2005) salah satunya adalah meningkatkan loyalitas pelanggan. Peningkatan loyalitas pelanggan akan meningkatkan tingkat penjualan perusahaan yang akan berpengaruh pada peningkatan profitabilitas perusahaan. Hasil penelitian Ekatah et al. (2011) juga menunjukkan bahwa CSR berkaitan positif dengan profitabilitas perusahaan. Berdasarkan penjelasan tersebut, maka hipotesis yang dapat dirumuskan dalam penelitian ini adalah:

$\mathrm{H}_{1}$ a: Kepemilikan institusional berpengaruh langsung terhadap profitabilitas.

$\mathrm{H}_{1}$ b: Kepemilikan institusional berpengaruh terhadap profitabilitas melalui corporate social responsibility sebagai variabel mediating. 
Hasil penelitian yang dilakukan oleh Setyarini dan Paramitha (2011) dengan populasi 174 perusahaan terkait dengan sumber daya alam yang terdaftar di Bursa Efek Indonesia tahun 2009, mengungkapkan bahwa terdapat pengaruh parsial antara kepemilikan manajerial terhadap pengungkapan tanggung jawab sosial perusahaan. Uraian di atas sesuai dengan teori legitimasi, teori stakeholder, dan teori social contract; dimana teori-teori tersebut menjelaskan bagaimana perusahaan perlu melakukan tanggung jawab sosial agar lingkungan dan masyarakat sekitar juga mendukung, dalam bentuk hubungan timbal balik, untuk perkembangan dan keberlanjutan bisnis perusahaan. Waddock dan Graves (1997) dalam Ekatah et al. (2011) juga menemukan hubungan yang signfikan positif antara indeks corporate social performance (CFP) dengan ukuran kinerja, seperti ROA, dalam periode tahun yang sama.

Jensen dan Meckling dalam Murwaningsari (2009) mengungkapkan bahwa kepemilikan manajerial sebagai investor internal akan menjalankan tugasnya dengan baik termasuk dalam meminimalkan agency problem untuk meningkatkan kinerja perusahaan dan secara otomatis meningkatkan tingkat pengembalian saham mereka. Berdasarkan penjelasan tersebut, maka hipotesis yang dapat dirumuskan dalam penelitian ini adalah:

$\mathrm{H}_{2}$ a: Kepemilikan manajerial berpengaruh langsung terhadap profitabilitas.

$\mathrm{H}_{2}$ b: Kepemilikan manajerial berpengaruh terhadap profitabilitas melalui corporate social responsibility sebagai variabel mediating.

Dewan komisaris independen akan membantu agar pengendalian internal lebih efektif dengan tidak adanya hasil pengawasan yang bias, oleh karena itu dewan komisaris independen sangat diperlukan dalam perusahaan. Pengendalian internal dan proses monitoring yang semakin efektif akan semakin memberi tekanan kepada manajemen untuk mengungkapkan sepenuhnya, termasuk pengungkapan tanggung jawab sosial. Page dalam Jamali et al. (2008) juga mengungkapkan bahwa kejujuran dan transparansi merupakan salah satu point penting dalam konsep GCG yang paling diharapkan oleh masyarakat baik dalam urusan bisnis ataupun pengungkapan sosial.

Ekatah et. al., (2011) juga Jo dan Harjoto (2012) yang menemukan bahwa semakin tinggi tingkat profitabilitas perusahaan maka saat itu juga pengungkapan tanggung jawab sosial yang dilakukan perusahaan juga semakin meningkat, dengan kata lain, tingginya pengungkapan tanggung jawab sosial berbanding lurus dengan peningkatan profitabilitas perusahaan. Setyawan dan Putri (2013) dalam penelitiannya yang mengukur GCG melalui asas-asas tersebut menemukan bahwa semakin baik penerapan GCG maka kinerja keuangannya juga akan mengalami peningkatan. Berdasarkan penjelasan tersebut, maka hipotesis yang dapat dirumuskan dalam penelitian ini adalah: 
$\mathrm{H}_{3}$ a: Dewan komisaris berpengaruh langsung terhadap profitabilitas.

$\mathrm{H}_{3}$ b: Dewan komisaris berpengaruh terhadap profitabilitas melalui corporate social responsibility sebagai variabel mediating.

Komite audit memiliki tugas untuk melakukan pemeriksaan dan pengawsan tentang proses pelaporan keuangan dan kontrol internal. Semakin baik kinerja komite audit dalam menjalankan tugasnya diharapkan akan semakin meningkatkan kepercayaan publik terhadap kelayakan dan objektivitas dari laporan keuangan perusahaan. Keputusan Ketua BAPEPAM dan LK dengan No. Kep-431/ BL/ 2012 mengatur mengenai tanggung jawab sosial perusahaan. Adanya komite audit sebagai pengawas agar perusahaan dapat memberikan laporan keuangan dan laporan tahunan dengan benar termasuk mengenai pengungkapan tanggung jawab sosial perusahaan. Lajili dan Zeghal dalam Murwaningsari (2009) mengungkapkan bahwa semakin banyak perusahaan mengungkapkan informasi mengenai human capital yang merupakan bagian dari CSR, akan semakin meningkatkan kinerja keuangan perusahaan.

Agung Suaryana dalam Wilopo (2011) menunjukkan bahwa komite audit yang semakin berkualitas akan berbanding lurus dengan kualitas laba. Aggarwal (2013) juga mengungkapkan bahwa komite audit merupakan salah satu faktor yang mempengaruhi kualitas tata kelola dan kinerja perusahaan. Berdasarkan penjelasan tersebut, maka hipotesis yang dapat dirumuskan dalam penelitian ini adalah:

$\mathrm{H}_{4}$ a: Komite audit berpengaruh langsung terhadap profitabilitas.

$\mathrm{H}_{4}$ b: Komite audit berpengaruh terhadap profitabilitas melalui corporate social responsibility sebagai variabel mediating.

\section{RESEARCH METHODS}

Penelitian ini menggunakan metode dokumentasi dalam proses pengumpulan data penelitian yaitu dengan mengumpulkan atau mengakses laporan keuangan (financial report) dan laporan tahunan (annual report) perusahaan manufaktur yang terdaftar di Bursa Efek Indonesia (BEI) pada http://www.idx.co.id serta data lain yang dapat digunakan dalam penelitian seperti data non keuangan yang berasal dari situs perusahaan yang menjadi sampel penelitian. Populasi yang digunakan dalam penelitian ini adalah perusahaan manufaktur sebanyak 132 perusahaan yang sahamnya tercatat di Bursa Efek Indonesia selama periode tahun 2008-2012.

Variabel exogenous dalam penelitian ini adalah Good Corporate Governance yang diukur dengan menggunakan proksi kepemilikan institusional, kepemilikan manajerial, dewan komisaris, dan komite audit.

1. Kepemilikan institusional

$$
\mathrm{KI}=\frac{\text { Jumlah saham milik institusional }}{\text { Jumlah saham yang beredar }} \times 100 \%
$$

2. Kepemilikan manajerial 


$$
\mathrm{KM}=\frac{\text { Jumlah saham milik manajerial }}{\text { Total saham beredar }} \times 100 \%
$$

3. Dewan komisaris Independen

$$
\text { DKI }=\frac{\text { Jumlah anggota dewan komisaris independen }}{\text { Jumlah anggota dewan komisaris }} \times 100 \%
$$

4. Komite audit

Dalam penelitian ini, komite audit diukur dengan melihat jumlah anggota komite audit dalam perusahaan.

Variabel endogenous perantara (mediasi), dalam penelitian ini, variabel tersebut adalah Pengungkapan Tanggung Jawab Sosial yang diukur dengan menggunakan proksi CSRDI (corporate social responsibility disclosure index) berdasarkan indikator GRI (global reporting initiatives) yang berfokus pada enam aspek pengungkapan tanggung jawab sosial, yaitu economic performance indicators (EC), environmental performance indicators (EN), labor practices dan decent work performance indicators (LA), human rights performance indicators (HR), society performance indicators (SO), serta product responsibility performance indicators (PR). Pengungkapan tanggung jawab sosial dalam penelitian ini diukur dengan menggunakan rumus sebagai berikut:

$$
\operatorname{CSRDI}_{\mathrm{j}}=\frac{\sum \mathrm{X}_{\mathrm{ij}}}{\mathrm{n}}
$$

Keterangan:

$\mathrm{CSRDI}_{\mathrm{j}}$ : Corporate Sosial Responsibility Discosure Index perusahaan j.

$\mathrm{X}_{\mathrm{ij}} \quad$ : variabel diukur menggunakan dummy variabel yaitu 1= jika item $\mathrm{i}$ diungkapkan, dan $0=$ jika item i tidak diungkapkan.

$\mathrm{n} \quad$ : jumlah item pengungkapan berdasarkan GRI, yaitu 84 item tanggung jawab sosial.

Variabel endogenous tergantung penelitian ini adalah Profitabilitas yang diukur dengan menggunakan proksi net profit margin (NPM). Profitabilitas perusahaan akan menunjukkan kemampuan perusahaan dalam memperoleh laba. Dalam penelitian ini profitabilitas akan diukur dengan menggunakan proksi net profit margin (NPM). Melalui perhitungan NPM dapat dilihat kemampuan perusahaan untuk menhasilkan keuntungan dalam rangka memberikan pengembalian (return) kepada pemegang saham. Perhitungan ini bertujuan untuk memberikan informasi mengenai kemampuan perusahaan dalam memberikan pengembalian kepada pemegang saham. Dalam perhitungan ini, laba bersih yang digunakan adalah laba perusahaan yang sudah siap untuk dibagikan kepada pemegang saham yaitu laba bersih setelah pajak (earning after tax atau EAT) sehingga rumus yang digunakan adalah sebagai berikut:

$$
N P M=\frac{\text { Net Income }(E A T)}{\text { Sales }}
$$


RESULT AND ANALYSIS

Tabel 1

Hasil Koefisien Path

\begin{tabular}{|c|c|c|c|c|c|}
\hline \multicolumn{3}{|c|}{ Path } & \multirow{2}{*}{$\begin{array}{l}\text { Std. Koefisien } \\
0,194\end{array}$} & \multirow{2}{*}{$\begin{array}{l}\text { Nilai Sig. }(<0,1) \\
0,035\end{array}$} & \multirow{2}{*}{$\begin{array}{l}\text { Keterangan } \\
\text { Signifikan }\end{array}$} \\
\hline Kep. Ins & $\rightarrow$ & Profitabilitas & & & \\
\hline Kep. Man & $\rightarrow$ & Profitabilitas & $-0,066$ & 0,459 & Tidak Signifikan \\
\hline & & & 0,308 & 0,0985 & Tidak Signifikan \\
\hline \multirow[t]{2}{*}{ Dewan Kom } & $\rightarrow$ & Profitabilitas & & & \\
\hline & & & 0,002 & 0,454 & Tidak Signifikan \\
\hline Kom. Audit & $\rightarrow$ & Profitabilitas & & & \\
\hline Kep. Ins & $\rightarrow$ & Peng. CSR & $-0,129$ & 0,172 & Tidak Signifikan \\
\hline Kep. Man & $\rightarrow$ & Peng. CSR & $-0,177$ & 0,053 & Signifikan \\
\hline Dewan Kom. & $\rightarrow$ & Peng. CSR & 0,055 & 0,532 & Tidak Signifikan \\
\hline Kom. Audit & $\rightarrow$ & Peng. CSR & $-0,080$ & 0,379 & Tidak Signifikan \\
\hline Peng. CSR & $\rightarrow$ & Profitabilitas & 0,066 & 0,000 & Signifikan \\
\hline
\end{tabular}

Sumber: Output SPSS, 2014

\section{a. Pengaruh Kepemilikan Institusional Terhadap Profitabilitas}

Pengaruh kepemilikan institusional terhadap profitabillitas $\left(\mathrm{H}_{1 \mathrm{a}}\right)$ adalah positif signifikan sebesar 0,035. Hal ini menunjukkan bahwa kepemilikan institusional dapat mempengaruhi tingkat profitabilitas dan hipotesis ini $\left(\mathrm{H}_{1 \mathrm{a}}\right)$ diterima. Hasil penelitian ini sejalan dengan hasil penelitian yang dilakukan oleh Riandi dan Siregar (2011). Cornett et. al (2007) juga medukung hasil penelitian ini yang mengungkapkan bahwa investor institusi dalam perusahaan akan menggunakan hak mereka sebagai pemegang saham dan menekan manajemen untuk meningkatkan kinerja perusahaan. Semakin banyak jumlah kepemilikan institusi akan meningkatkan pengawasan pada manajemen untuk bertindak sesuai kepentingan investor yaitu peningkatan kinerja. Rata-rata kepemilikan institusional dalam perusahaan yang digunakan sebagai sampel dalam penelitian ini cukup tinggi sehingga dapat mendukung pelaksanaan fungsi monitoring secara lebih intensif dan membantu manajemen untuk melakukan kegiatan operasional lebih baik. Hal ini mungkin dapat dijelaskan dengan alasan bahwa usaha investor institusional dalam melakukan kegiatan oportunistik adalah karena investor institusional tidak berorientasi pada laba jangka pndek melainkan pada laba yang bersifat berkelanjutan dan laba jangka panjang. Beberapa manfaat adanya kepemilikan institusional sebagai salah satu struktur GCG menurut Maksum (2005) adalah meminimalkan adanya penyalahgunaan wewenang oleh pihak direksi dalam pengelolahan perusahaan dan meningkatkan kualitas laporan keuangan perusahaan.

\section{b. Pengaruh Kepemilikan Institusional Terhadap Profitabilitas Melalui Pengungkapan CSR Sebagai Variabel Mediating}

Kepemilikan institusional terhadap pengungkapan CSR berpengaruh negatif dan tidak signifikan dengan nilai signifikansi sebesar 0,172 dan pengungkapan CSR 
berpengaruh positif dan signifikan terhadap profitabilitas dengan nilai signifikansi sebesar 0,000 . Arah koefisien hubungan tidak langsung menunjukkan arah yang negatif yaitu sebesar $-0,0085(-0,129 \times 0,066)$ sedangkan pengaruh langsung antara kepemilikan institusional terhadap profitabilitas adalah sebesar 0,194. Oleh karena itu, hipotesis yang menyatakan bahwa kepemilikan institusional berpengaruh terhadap profitabilitas melalui pengungkapan CSR sebagai variabel mediating $\left(\mathrm{H}_{1 \mathrm{~b}}\right)$ tidak diterima. Hasil penelitian ini menunjukkan bahwa persentase kepemilikan institusional tidak dapat meningkatkan kepatuhan manajemen untuk melakukan pengungkapan CSR yang diharapkan dapat meningkatkan profitabilitas perusahaan. Sejalan dengan hasil penelitian ini, Purbopangestu (2014) juga mengungkapkan bahwa kepemilikan insitusional tidak memiliki pengaruh yang signifikan terhadap pengungkapan CSR dikarenakan kepemilikan institusional tidak mempertimbangkan pengungkapan CSR sebagai salah satu pertimbangan yang mereka lakukan dalam membuat keputusan berinvestasi. Pemahaman dan kesadaran mengenai pengungkapan CSR bagi perusahaan manufaktur di Indonesia yang masih rendah dapat menjadi penyebab investor institusional belum tertarik untuk menjadikan pengungkapan CSR sebagai salah satu pertimbangan mereka dalam membuat keputusan investasi.

\section{c. Pengaruh Kepemilikan Manajerial Terhadap Profitabilitas}

Pengaruh kepemilikan manajerial terhadap profitabillitas $\left(\mathrm{H}_{2 a}\right)$ adalah negatif dan tidak signifikan dengan nilai signifikan sebesar 0,459. Hal ini menunjukkan bahwa peningkatan atau penurunan pada persentase kepemilikan manajerial tidak berpengaruh pada peningkatan profitabilitas. Faktor yang mungkin menjadi penyebab hipotesis penelitian ini tidak diterima adalah karena investor internal lebih berfokus pada kegiatan oportunistik mereka sendiri. Rata-rata kepemilikan manajerial pada perusahaan manufaktur yang terdaftar di Bursa Efek Indonesia Tahun 2008-2012 masih sedikit. Hasil penelitian ini juga sejalan dengan hasil penelitian dari Coskun dan Sayilir (2012) yang tidak menemukan adanya hubungan yang signifikan dari corporate governance terhadap kinerja keuangan perusahaan. Selain karena rendah-nya tingkat kepemilikan manajerial dalam perusahaan manufaktur di Indonesia, alasan lain yang mungkin dapat menjelaskan hubungan yang tidak signifikan antara kepemilikan manajerial terhadap profitabilitas adalah terjadinya bias. Jika terdapat kepemilikan manajerial dalam perusahaan maka investor internal tersebut cenderung akan menyalahgunakan wewenang mereka sebagai investor sekaligus sebagai pelaksana kegiatan operasional perusahaan.

\section{d. Pengaruh Kepemilikan Manajerial Terhadap Profitabilitas Melalui Pengungkapan CSR Sebagai Variabel Mediating}


Kepemilikan manajerial terhadap pengungkapan CSR berpengaruh negatif dan signifikan dengan nilai signifikansi sebesar 0,053 dan pengungkapan CSR berpengaruh positif dan signifikan terhadap profitabilitas dengan nilai signifikansi sebesar 0,000. Arah koefisien hubungan tidak langsung menunjukkan arah yang negatif yaitu sebesar $-0,0116$ $(-0,177 \times 0,066)$ sedangkan pengaruh langsung antara kepemilikan manajerial terhadap profitabilitas adalah sebesar $-0,066$. Oleh karena itu, hipotesis yang menyatakan bahwa kepemilikan manajerial berpengaruh terhadap profitabilitas melalui pengungkapan CSR sebagai variabel mediating $\left(\mathrm{H}_{2 \mathrm{~b}}\right)$ diterima.

Hasil penelitian ini menunjukkan bahwa adanya kepemilikan manajerial dalam perusahaan mampu berperan sebagai pendukung terciptanya pengungkapan CSR yang nantinya akan memberikan nilai positif pada peningkatan profitabilitas perusahaan. Pihak manajerial yang sekaligus menjadi salah satu pemilik saham dalam perusahaan tersebut akan lebih memahami bagaimana kondisi perusahaan karena mereka juga terlibat dalam kegiatan operasional perusahaan termasuk dalam berinteraksi langsung dengan karyawan, masyarakat, dan lingkungan sekitar. Hal ini tampaknya dapat menjadi penjelasan saat adanya investor manajerial dalam suatu perusahaan maka akan semakin mendorong manajemen untuk melakukan tindakan sosial dan mengungkapkannya. Sejalan dengan penjelasan di atas, Setyarini dan Paramitha (2011) juga mengungkapkan bahwa kepemilikan manajerial memiliki hubungan yang parsial terhadap pengungkapan tanggung jawab sosial perusahaan. Murwaningsari (2009) juga menemukan adanya pengaruh secara parsial dan signifikan antara ketiga variabel yaitu kepemilikan manajerial sebagai salah satu proksi dari GCG, pengungkapan CSR, dan corporate financial performance.

\section{e. Pengaruh Dewan Komisaris Terhadap Profitabilitas}

Pengaruh dewan komisaris terhadap profitabillitas $\left(\mathrm{H}_{3 a}\right)$ adalah positif dan tidak signifikan. Hal ini menunjukkan bahwa peningkatan jumlah komisaris independen yang merupakan pengukuran dewan komisaris tidak mempengaruhi peningkatan profitabilitas perusahaan. Hasil penelitian ini mendukung hasil penelitian dari Yushita et al, (2013). Proporsi dewan komisaris independen sebagai proksi dari dewan komisaris tidak dapat mempengaruhi keuntungan perusahaan. Alasan yang mungkin dapat menjelaskan hal ini adalah minimnya kompetensi dari dewan komisaris independen untuk meningkatkan suasana yang objektif dan mempertimbangkan prinsip kesetaraan (fairness) bagi pemegang saham minoritas dan stakeholder lainnya.

Tingkat independensi yang masih rendah dari dewan komisaris independen juga menjadi alasan dewan komisaris independen tidak mampu memberikan pengaruh pada peningkatan profitabilitas perusahaan. Alijoyo dan Zaini (2004) juga menjelaskan bahwa rendahnya independensi komisaris menjadi tantangan dalam pertumbuhan bisnis di Indonesia. Selain itu, rendahnya tingkat kompetensi juga dapat menjadi penjelasan 
dewan komisaris tidak mampu mempengaruhi profitabilitas. Alijoyo dan Zaini (2004) juga mengungkapkan bahwa rendahnya tingkat kompetensi dan integritas dewan komisaris terjadi ketika pengangkatan komisaris dilakukan hanya sebagai suatu penghargaan semata.

\section{f. Pengaruh Dewan Komisaris Terhadap Profitabilitas Melalui Pengungkapan CSR Sebagai Variabel Mediating}

Dewan komisaris terhadap pengungkapan CSR berpengaruh positif dan tidak signifikan dengan nilai signifikansi sebesar 0,532 dan pengungkapan CSR berpengaruh positif dan signifikan terhadap profitabilitas dengan nilai signifikansi sebesar 0,000 . Arah koefisien hubungan tidak langsung menunjukkan arah yang positif yaitu sebesar 0,0036 $(0,055 \times 0,066)$ sedangkan pengaruh langsung antara dewan komisaris terhadap profitabilitas adalah sebesar 0,308 . Oleh karena itu, hipotesis yang menyatakan bahwa dewan komisaris berpengaruh terhadap profitabilitas melalui pengungkapan CSR sebagai variabel mediating $\left(\mathrm{H}_{3 b}\right)$ tidak diterima. Hasil pengujian hipotesis ini menunjukkan bahwa adanya dewan komisaris independen dalam suatu perusahaan tidak mampu mendorong manajemen untuk melakukan dan mengungkapkan CSR sebagai bentuk tanggung jawab sosial perusahaan. Berdasarkan hasil penelitian ini yang menunjukkan bahwa dewan komisaris independen tidak memiliki pengaruh yang signifikan terhadap pengungkapan CSR dapat mencerminkan bahwa tingkat independensi dan komposisi dewan komisaris independen sebesar 30\% tidak cukup kuat untuk membuat keberadaan mereka diakui oleh manajamen perusahaan. Alijoyo dan Zaini (2004) juga mngungkapkan bahwa budaya masyarakat Indonesia yang masih memiliki sikap enggan atau tidak tegas dalam memberi kritik. Purbopangestu (2014) yang juga menemukan bahwa CSR tidak dapat menjadi variabel mediating pada hubungan antara dewan komisaris independen terhadap nilai perusahaan dengan alasan bahwa keterbatasan kewenangan dari komisaris indepen-den dalam perusahaan membuat mereka tidak dapat ikut campur dalam pengambilan keputusan pelaksanaan CSR.

\section{g. Pengaruh Komite Audit Terhadap Profitabilitas}

Pengaruh komite audit terhadap profitabillitas $\left(\mathrm{H}_{4 a}\right)$ adalah positif dan tidak signifikan dengan nilai signifikan sebesar 0,454. Hal ini menunjukkan bahwa jumlah komite audit dari sampel perusahaan yang digunakan dalam penelitian ini tidak memiliki pengaruh pada kondisi profitabilitas perusahaan. Hasil uji hipotesis ini mendukung hasil penelitian Yushita et al (2013) yang menemukan bahwa komite audit tidak memiliki pengaruh terhadap kinerja keuangan. Yushita et al (2013) juga mengungkapkan bahwa komite audit yang merupakan salah satu dari struktur GCG tidak dapat mencegah tindak manipulasi laba.

Published by University of Airlangga.

This is an open access article under the CC BY license (https://creativecommons.org/licenses/by-sa/4.0/) 
Alasan lain yang mungkin dapat menjelaskan hipotesis ini tidak diterima adalah bahwa adanya komite audit dalam suatu perusahaan hanya berfokus ada pengawasan dan pemeriksaan laporan keuangan perusahaan. Peraturan mengenai pembentukan dan pedoman pelaksanaan kerja komite audit yang dimuat dalam Keputusan Ketua Bapepam dan LK (Kep-643/BL/2012) menjelaskan bahwa komite audit harus bertindak secara independen. Integritas komite audit mungkin dapat menjadi salah satu faktor yang menyebabkan fungsi dan tanggung jawab komite audit tidak berjalan dengan efektif.

\section{h. Pengaruh Komite Audit Terhadap Profitabilitas Melalui Pengungkapan CSR Sebagai Variabel Mediating}

Komite audit terhadap pengungkapan CSR berpengaruh negatif dan tidak signifikan dengan nilai signifikansi sebesar 0,379 dan pengungkapan CSR berpengaruh positif dan signifikan terhadap profitabilitas dengan nilai signifikansi sebesar 0,000 . Arah koefisien hubungan tidak langsung menunjukkan arah yang negatif yaitu sebesar $-0,0052$ $(-0,080 \times 0,066)$ sedangkan pengaruh langsung antara dewan komisaris terhadap profitabilitas adalah sebesar 0,002 . Oleh karena itu, hipotesis yang menyatakan bahwa komite audit berpengaruh terhadap profitabilitas melalui pengungkapan CSR sebagai variabel mediating $\left(\mathrm{H}_{4 b}\right)$ tidak diterima. Hal ini mungkin dapat dijelaskan karena tugas komite audit dalam memberi pandangan mengenai masalah perusahaan yang berkaitan dengan kebijakan keuangan, akuntansi, dan pengendalian internal tampaknya belum berjalan secara efektif sehingga tidak mampu memotivasi manajemen untuk melakukan dan mengungkapkan CSR.

Sesuai dengan tugas dari komite audit seperti yang diungkapkan Susiana dan Herawaty dalam Guna dan Herawaty (2010), mencerminkan bahwa komite audit tidak memiliki perhatian pada bagaimana perusahaan melakukan bentuk tanggung jawab sosialnya terhadap lingkungan dan masyarakat. Selain itu, keterbatasan wewenang dari komite audit juga dapat membatasi mereka untuk membuat kebijakan atau keputusan yang dapat mendorong perusahaan dalam melakukan pegungkapan CSR yang dilakukan perusahaan tersebut. Hasil penelitian ini menunjukkan bahwa melalui pengungkapan CSR, komite audit tidak dapat memberikan pengaruh terhadap profitabilitas perusahaan. Sesuai peraturan dalam yang dimuat dalam Keputusan Ketua Bapepam dan LK (Kep643/BL/2012), hasil ini juga mendukung asumsi bahwa komite audit disinyalir hanya melakukan fungsi dan wewenang mereka dalam membantu dewan komisaris yaitu menelaahan informasi keuangan tanpa terlibat langsung dalam penyelesaian masalah keuangan perusahaan.

\section{CONCLUSION}

Berdasarkan pengujian hipotesis yang dilakukan, maka hasil penelitian dapat disimpulkan bahwa kepemilikan institusional terbukti berpengaruh langsung dan 
signifikan terhadap profitabilitas perusahaan dengan proksi NPM. Namun, pengungkapan CSR tidak terbukti dapat menjadi variabel mediating dalam hubungan antara kepemilikan institusional terhadap profitabilitas perusahaan. Kepemilikan manajerial tidak terbukti berpengaruh secara langsung terhadap profitabilitas perusahaan dengan proksi NPM. Namun, melalui pengungkapan CSR terbukti dapat menjadi variabel mediating antara kepemilikan manajerial terhadap profitabilitas perusahaan. Dewan komisaris yang diproksikan dengan persentase dewan komisaris independen tidak terbukti berpengaruh terhadap profitabilitas, baik secara langsung maupun melalui pengungkapan CSR sebagai variabel mediating. Komite audit tidak terbukti berpengaruh terhadap profitabilitas, baik secara langsung maupun melalui pengungkapan CSR sebagai variabel mediating.

Diharapkan bagi peneliti selanjutnya untuk menambahkan sektor industri lain, (seperti industri; perbankan, pertambangan) sehingga kekuatan generalisasi dari hasil penelitian dapat lebih luas dan lebih kuat. Menambahkan proksi lain dari profitabilitas selain NPM, (seperti: EPS, ROA, ROE) sehingga mampu memberikan hasil yang dapat diperbandingkan dan lebih menjelaskan pengaruh variabel independen terhadap peningkatan profitabilitas

\section{REFERENCES}

Aggarwal, Priyanka. 2013. CorporateGovernance and Corporate Profitability: Are they Related? - A Study in Indian Contect. International Journal of Scientific and Research Publications, Vol 3, Issue 12.

Cheng, Megawati dan Yulius Jogi Christiawan. 2011. Pengaruh Pengungkapan Corporate Social Responsibility Terhadap Abnormal Return. Jurnal Akuntansi dan Keuangan.Vol.13, No. 1. Pp 24-36.

Coskun, Metin dan Ozlem Sayilir. 2012. Relationship Between Corporate Governace and Financial Performance of Turkish Companies. International Journal of Business and Social Science. Vol.3 No. 14.

Daniri, Mas Achmad. 2005. Good Corporate Governance Konsep dan Penerapannya dalam Konteks Indonesia. Jakarta. PT. Ray Indonesia.

Ekatah, Innocent., Martin Samy, Roberta Bampton, Abdel Halabi. 2011. The Relationship Between Corporate Social Responsibility and Profitability: The Case of Royal Dutch Shell Plc. Corporate Reputation Review. Vol 14. No. 4. Pp 249-261.

Freeman, R. Edward. 1994. The Politics of Stakeholder Theory: Some Future Directions. Business Ethics Quarterly, Vol. 4. No. 4. Pp 409-421.

Gray, R., et al. 2001. Social and Environmental Disclosure, And Corporate Characteristic: A Research Note And Extension. Journal of Bussiness Finance and Accounting. Vol. 8. No. 3.

http://www. bapepam.go.id/uu

Published by University of Airlangga.

This is an open access article under the CC BY license (https://creativecommons.org/licenses/by-sa/4.0/) 
http://www.idx.co.id

Guna, I Melvin, Arleen Herawaty. 2010. Pengaruh Mekanisme Good Corporate Governance, Independensi Auditor, Kualitas Audit dan Faktor Lainnya Terhadap Manajemen Laba. Jurnal Bisnis dan Akuntansi. Vol. 12, No. 1. Pp 53-68.

Jamali, Dima, Asem M. Safieddine dan Myriam Rabbath. 2008. Corporate Governance And Corporate Social Responsibility Synergies And Interrelationships. Journal Compilation. Vo 16. No.5.

Jati, Framudyo. 2009. Pengaruh Struktur Corporate Governance Tehadap Kinerja Perusahaan Manufaktur Yang Terdaftar di Bursa Efek Indonesia. Jurnal Akuntansi Fakultas Ekonomi Universitas Gunadarma.

Jo, Hoje and Maretno A. Harjoto. 2011. Corporate Governance and Firm Value: The Impact of Corporate Social Responsibility. Journal Bussiness Ethic. 103: 351-383. . 2012. The Casuall Effect of Corporate Governance on Corporate Social Responsibility. Journal Bussiness Ethics 106: 53-72.

Khan, Md. Habib-Uz-Zaman. 2010. The Effect of Corporate Governance Elements on Corporate Social Responsibility (CSR) Reporting. International Journal of Law and Management. Vol 52. No. 2. Pp 82-109.

Kotler, P. dan N. Lee, E. WY. 2006. The Effect of Service Recovery on Consumer Satisfaction: A Comparison Between Complaint and Non- Complaint. Journal of Service Marketing. Vol 20. No. 2. Pp 101-111.

Kuswandi, Ir., MBA. 2006. Memahami Rasio-Rasio Keuangan Bagi Orang Awam. Jakarta: PT. Elex Media Komputindo, Gramedia Group.

Mallin, Christine. 2004. Corporate Governance. New York: Oxford University Press.

Munawir. 2007. Analisis Laporan Keuangan. Edisi Keempat. Yogyakarta: Liberty.

Murwaningsari, Etty. 2009. Hubungan Corporate Governance, Corporate Social Responsibilities dan Corporate Financial Performance Dalam Satu Continuum. Jurnal Akuntansi dan Keuangan. Vol.11. No.1. pp. 30-41.

Prihadi, Toto. 2008. Tujuh Analisis Rasio Keuangan: Deteksi Cepat Kondisi Keuangan. Jakarta: PPM.

Purbopangestu, Hary Wisnu. 2014. Engaruh Good Corporate Governance Terhadap Nilai Perusahaan Dengan Corporate Social Responsibility Sebagai Variabel Intervening. Accounting Analysis Journal 3 (3) (2014).

Retno, Reny Dyah M., Denies Priantinah M.Si., Ak. 2012. Pengaruh Good Corporate Governance Dan Pengungkapan Corporate Social Responsibility Terhadap Nilai Perusahaan (Studi Empiris Pada Perusahaan Yang Terdaftar Di Bursa Efek Indonesia Periode 2007-2010). Jurnal Nominal. Vol. 1. No. 1.

Riandi, Dani dan Hasan Sakti Siregar. 2011. Pengaruh Penerapan Good Corporate Governance Terhadap Return On Asset, Net Profit Margin, Dan Earning Per Share Pada Perusahaan Yang Terdaftar Di Corporate Governance Perception Index. Jurnal Ekonomi. Vol 14, No 3.

Setyarini, Yulia dan Melvie Paramitha. 2011. Pengaruh Mekanime Good Corporate Governance Terhadap Corporate Social Responsibility. Jurnal Kewirausahaan. Vol. 5. No. 2. 
Setyawan, Komang Meitradi dan I Gusti Ayu Made Asri Dwijaya Putri. 2013. Pengaruh Good Corporate Governance Terhadap Kinerja Keuangan Lembaga Perkreditan Desa Di Kecamatan Mengwi Kabupaten Badung. E-Jurnal AKuntansi Universitas Udayana. Vol. 5 No. 3. Pp 586-598.

Siahaan, Fadjar O.P. 2013. The Effect of Good Corporate Governance Mechanism, Laverage, and Firm Size on Firm Value. GSTF International Journal on Business Review (GBR). Vol 2. No. 4.

Siswanto, Sutojo dan Aldridge, E. John. 2005. Good Corporate Governance : Tata Kelola Perusahaan Yang Sehat. Jakarta: Pt. Damar Mulia Rahayu.

Wilopo, David T.R. 2011. Pengaruh Good corporate governance (GCG) Terhadap Profitabilitas Dan Kinerja Saham Perusahaan Perbankan Yang Tercatat Di Bursa Efek Indonesia. Journal of Business and Banking. Vol. 1. No. 1. Pp. 1-14.

Yushita, A. Novi, Rahmawati, dan Hanung Triatmoko. 2013. Pengaruh Mekanisme Corporate Governance, Kualitas Auditor Eksternal, dan Likuiditas terhadap Profitabilitas. Jurnal Economia. Vol. 9. No. 2. 